\title{
Rabies: $100 \%$ Preventable but Remains a Daily Threat to Millions around the World, a Comprehensive Review
}

\author{
*Furqan Munir ${ }^{1}$ \\ *Corresponding author: furqanmunir66@gmail.com \\ Rida Asrar ${ }^{2}$ \\ vetrida66@gmail.com \\ Momina Ahsan ${ }^{3}$ \\ mominaahsan120@gmail.com \\ Areej Asif ${ }^{4}$ \\ areejasif901@gmail.com
}

Abdul Hakeem Shah ${ }^{5}$

abdulhakeem.shah.77@gmail.com

Faculty of Veterinary Science, University of Agriculture

Faisalabad, Pakistan

DOI: 10.31364/SCIRJ/V9.i02.2021.P0221XX

http://dx.doi.org/10.31364/SCIRJ/v9.i02.2021.P0221XX

\begin{abstract}
Rabies is a serious viral disease of mammals that causes acute inflammation of the brain in animals. It is a zoonotic, fatal, and progressive neurological infection. The virus responsible for this belongs to the family Rhabdoviridae, genus Lyssavirus. It affects warm-blooded animals and the disease is prevalent throughout the world and endemic in many countries except Antarctica and Australia. The virus enters the body through a rabid animal bite. Currently, there is no specific treatment for rabies if clinical signs appear. We can control rabies through regular vaccination of ourselves and our pets.
\end{abstract}

Index Terms- Rabies, pathogenesis, transmission, prophylaxis, vaccination

\section{INTRODUCTION}

Rabies is also called hydrophobia or rage. Rabies is a serious viral disease that causes acute inflammation of the brain in humans and other warm-blooded animals. Rabies is transmitted from rabid animals to humans. It can be transmitted when an infected animal scratches or bites human or other animals. It can also be transmitted through the saliva of an infected person or animal if it meets the mucous membranes of healthy animals or humans. In humans, most cases are seen due to the bite of rabid dogs. About $99 \%$ of cases are reported having a history of rabid dog bites. By the time the symptoms will appear and now it is very late to save the life of an infected individual. However, a person who may have been infected with rabies can be treated effectively when seeks help at once. For treatment to be successful, it must be given before the appearance of symptoms. Without early treatment, it is usually fatal. Following the vaccination requirements for pets can be helpful in the prevention and control of this disease.

Rabies virus is a non-segmented, negative-stranded, RNA virus that belongs to the family Rhabdoviridae which includes at least three genera of animal viruses i.e., Ephemerovirus, Lyssavirus, and Vesiculovirus. Rabies virus belongs to the genus Lyssavirus. Many strains of this virus are species-specific and associated with different species.

Although rabies is an ancient disease, human rabies is a continuous problem in developing countries. In developing countries, it is often unrecognized until late during disease or postmortem because physicians are not familiar with the clinical manifestation of rabies disease. This disease can be prevented after exposure with the cleaning of wounds and administration of vaccines against rabies and rabies immune globulins. There is no established effective treatment once rabies develops, it is almost always fatal once symptoms occur. 


\section{HISTORY OF RABIES}

Rabies is an ancient disease and its history is very long that is lost in antiquity. According to Athenodorus, it was first observed in human beings in the days of the Asclepiadae, the descendent of the god of medicine Aesculapius. The Greeks called rabies Lyssa which means madness. The disease in man is described as hydrophobia or rage because the infected individual is tormented at the same time with fear of water and thirst. The Latin word rabies is derived from an old Sanskrit word "rabhas" which means to do violence. Some 500 years B.C., Democritus is thought to have made the first recorded description of canine rabies. Aristotle, in the $4^{\text {th }}$ century B.C., wrote it as dogs suffer from madness. This causes them to become seriously irritable and all animals they bite into becoming diseased. For the prevention of rabies, in ancient medical times, the attachment of the tongue (the frenum linguae) was cut and a fold was removed in which the causative agent was thought to be present. This idea was practiced until the $19^{\text {th }}$ century when Louis Pasteur described the cause of rabies.

Fermi, in the review of a huge number of experiments, pointed out the difficulty of demonstrating rabies virus in the saliva. Bartarelli showed that the rabies virus reached the salivary glands of rabid dogs by peripheral nerves. He cut the nerve supply of one parotid gland in an animal, after which the animal was inoculated with the rabies virus. The gland with severed nerve supply contained almost no rabies virus, but those glands in which the nerve supply was left intact, produced rabies in other animals. Meanwhile, some scientists observed that the rabies virus could be found in the saliva of rabid dogs 2 or 3 days before the least clinical symptoms.

\section{HOW IS RABIES TRANSMITTED?}

\section{A. By infected animal bite.}

Rabies is transmitted when an infected animal bites a healthy animal or human which is the most common route, and contamination of scratch wounds by virus-infected saliva. However, there are certainly other routes that have been implicated in the past include through mouth mucous membranes, conjunctiva, genitalia, and anus. Aerosol transmission is also demonstrated in laboratory animals, in humans through rabies-infected bat caverns, and in many laboratory accidents because, in caves, there is the sprinkling of bat's urine and saliva. All animals including rodents, canids, and felines can transmit disease, but in $99 \%$ of cases human rabies is transmitted by a rabid dog bite and 0.1 to $1 \%$ is through dog scratches. Vampire bats, insect bats, and flying foxes, all contain the rabies virus. In vampire bats, there are no clinical signs, but the virus is present in their saliva. Bats are considered a reservoir for the virus, but all other rabid animals can transmit disease and cause symptoms. Every bat bite should be vaccinated because it is a reservoir host, but every dog bite is not necessary to be vaccinated. There were five instances in humans in which disease is transmitted from one man to others through the transplantation of infected corneas. The non-bite exposures include contamination of scratch, open wounds, abrasion, or mucous membrane by saliva or central nervous tissue from an infected animal.

\section{B. Risk factors of rabies include}

Bite of a dog infected with rabies, Injection of a live modified vaccine in immunocompromised patients, laboratory persons or researchers working in the laboratory with rabies virus, having pets at home, dealing with zoo animals, and having pre-bite or post-bite of infected animals.

\section{WHO CAN GET RABIES?}

All mammals can get rabies, including humans or it can infect all warm-blooded animals. The most common reservoirs of rabies include wolves, foxes, and raccoons which are highly susceptible, humans, dogs, cats, sheep, goat, cattle, buffalo, and horses which are moderately susceptible, and birds are rarely infected.

\section{INCUBATION PERIOD}

The incubation period is defined as the period between the invasion of a pathogen till the onset of clinical signs and symptoms. The incubation period of rabies is variable and may range from 2 to 8 weeks and may extend up to 24 weeks.

\section{PATHOGENESIS OF DISEASE}

Much of what is known about rabies pathogenesis is learned from the experiments or studies performed on laboratory animals e.g., rodents. After the entry of virus or inoculation when a rabid animal bites into the subcutaneous tissues and muscles, the virus starts its replication in the connective or striated tissue at the site of entrance and then enters the peripheral nerves through the neuromuscular junction by binding with the nicotinic acetylcholine receptors. In the spinal cord, its multiplication occurs. After this, it starts spreading to the central nervous system in the endoneurium of Schwann cells of motor and sensory axons and reach the grey matter of the brain. After the bite, the virus reaches the ganglion in the spinal cord and then to the brain through centripetal force. Then it causes encephalitis and continues spreading throughout the whole body and infects salivary glands. After infecting the salivary glands, the virus appears in the saliva. Viruses multiply in deep tissues due to less oxygen.

\section{SEMIOLOGY OR CLINICAL SIGNS}

Generally, there are three stages of rabies, but the fourth phase is also considered, known as the atypical phase. Following are the phases or stages of rabies
A. Prodromal stage or dumb form
B. Furious stage
C. Paralytic stage
D. Atypical stage
A. Prodromal or dumb form

This stage lasts for 2 to 4 days. Animals pass this phase unnoticed. The signs of this stage include erratic behavior which 
means whenever the animal is a pet, it has strange behavior with the owner.

\section{B. Furious stage}

This stage lasts for 2 to 4 days, as in the previous stage. In this stage, many changes are observed in the animals. The animals become furious, there is an increase in body temperature or fever, abnormal gait, chewing, biting non-food items, aimless wondering, dilation of the pupil, and spasm of the eye, eyeball, or cornea.

\section{Paralytic form}

This stage lasts for 2-4 days, as in the previous stages. This is the typical form of rabies because everyone can identify this stage. In this stage, there is paralysis of lower motor and cranial nerves, and death will occur within 3 to 7 days after the appearance of this stage. Cranial paralysis results in the following symptoms

- Animals suffer from ascending paralysis, and paralysis of biting organs.

- Laryngeal paralysis that results in voice change.

- Pharyngeal paralysis that results in dysphagia (abnormal eating), drooling of saliva, irregular contraction of pharyngeal tissue, when saliva will finish, the mouth will become dry.

- Masticatory paralysis results in irregular chewing and hanging jaws.

- Generalized paralysis results in disorientation, struggling gait, convulsion, seizure, and champing (aggressiveness).

- Death will occur due to respiratory paralysis.

D. Atypical stage or form

Vampire bats are considered reservoir hosts.

\section{LABORATORY DIAGNOSIS}

Rabies is diagnosed based on clinical signs in antemortem cases. Most tests in the case of rabies are not sensitive. If we perform the histopathology of the brain of a rabid animal, we can see inclusion bodies in the slide. Other tests for rabies include the DFA test which stands for Direct fluorescent antibody test, mouse inoculation, tissue culture, and molecular analysis e.g., detection of virus RNA. If the DFA test of the animal is positive, then we inject some pieces of brain intra-cerebrally into the mouse for further confirmation. If we perform tests on the frozen sample, then all the above tests may give false-negative results, so avoid freezing of the sample. Keep the sample at $4^{\circ} \mathrm{C}$ and liquid ice is not required because it may freeze the sample.

\section{TREATMENT}

Currently, there is no specific treatment available if the onset of disease or clinical signs appears.

\section{A. How can we protect ourselves and our animals?}

The best and effective protection against rabies infection is solely the vaccination of pets and avoidance of risk factors that have been discussed before. Dog and cat require vaccination. Make sure you are vaccinating your animals and keep your animals indoor to avoid their contact with other wild or rabid animals. If the rabid animal is captured, always fire the animal from a distance and never try to euthanize the animal.

\section{B. Prophylactic measures}

There are two types of prophylactic measures in animals and humans

1. Pre-exposure prophylaxis (PrEP)

2. Post-exposure prophylaxis (PEP)

Pre-exposure prophylaxis

(1) In dogs and cats

- Inject the first shot of vaccine against rabies at the age of 3 months because before 3 months, there is no production of antibodies due to the absence of receptors.

- Inject the second booster shot of the vaccine 2 to 3 weeks after the first shot.

- Inject the third shot at the age of $6^{\text {th }}$ months.

- After this, give the fourth shot every year.

Post-exposure prophylaxis

(2) In dogs, cats, sheep, goats, and small calves

- Inject the first two (double) shots on 0 days or we can say on the day of biting.

- Inject the second single shot on the $7^{\text {th }}$ day after the first shot.

- And finally, administer the third single shot on the $21^{\mathrm{st}}$ day after the first shot.

(3) In donkeys, horses, and cows

- Inject the first three (triple) shots on 0 days.

- Inject the second two (double) shots on the $7^{\text {th }}$ day after the first shot.

- And finally, Inject the third two (double) shots on the $21^{\text {st }}$ day after the first shot.

(4) In Buffalo and camels

- Inject the first four shots on 0 days.

- Inject the second three (triple) shots on the $7^{\text {th }}$ day after the first shot.

- And finally, give third three (triple) shots on the $21^{\text {st }}$ day after the first shot.

(5) In hippo, rhino, and elephants

- Inject the first five shots on 0 days.

- Inject the second four shots on the $7^{\text {th }}$ day after the first shot.

- And finally, give third four shots on the $21^{\text {st }}$ day after the first shot.

(One single shot of rabies vaccine is equal to $1 \mathrm{CC}$ or $1 \mathrm{ml}$.) 
Precaution- Do not give all the shots at the same point in animals. Change site in every shot. All shots should be given subcutaneously in different sites at the same time in both preexposure and post-exposure.

\section{Protocol in Humans}

Pre-exposure prophylaxis

- Inject the first single shot of vaccine against rabies

- Inject the second single shot of vaccine against rabies on the $3^{\text {rd }}$ day after the first shot.

- Administer the third single shot of vaccine on the $7^{\text {th }}$ or $14^{\text {th }}$ day after the first shot.

Post-exposure prophylaxis

- Administer the first single shot on 0 days.

- Administer the second single shot on the 3rd day after the first shot.

- Administer the third single shot on the $7^{\text {th }}$ day after the first shot.

- Inject the fourth single shot on the $14^{\text {th }}$ day after the first shot.

- Finally, administer the fifth shot on the $21^{\text {st }}$ day after the first shot.

The recommended site for human vaccination against rabies is the deltoid muscle preferably the lateral side of the deltoid muscle.

\section{Management of wound}

(1) If the wound is superficial and not bleeding

- Bleeding should be encouraged to increase oxygen or to make an oxygenated environment.

(2) If there is a large wound

- Stop bleeding as soon as possible to avoid blood loss.

(3) Small wound but bleeding

- Washing with soap or alcohol (ethanol) is approved.

- Dip biting area in benzalkonium chloride for 2 hours.

- Scrubbing biting site under running water is required.

(4) Perforating wound or wound at the abdominal cavity

- Explore the wound and observe inside the cavity to manage the internal wound.

(5) Wound at the thoracic region

- First, ensure negative pressure and then manage the wound.

The wound must be opened after 2 or 3 days to ensure the oxygenated environment, and then apply a bandage. Generally, we leave the wound open. After all these protocols, we must provide antibiotics, antipyretic, NSAID, wound healing agents, symptomatic treatment and antiseptic, etc.

\section{CONCLUSION}

Rabies is a zoonotic disease that can spread from rabid animals to normal animals, even humans. It is $100 \%$ preventable but remains a threat to millions of people around the globe. We can prevent this disease through vaccination and proper management. We must vaccinate ourselves and our pets. Currently, there is no specific treatment against rabies if clinical signs appear so that we must manage and prevent its spread by following the recommended protocols.

\section{REFERENCES}

[1] Abelseth MK. 1964. An attenuated rabies vaccine for domestic animals produced in tissue culture. Can Vet J. 5:279-286.

[2] ACPA (Asia Canine Protection Alliance). 2013. Risk assessment-the risk the dog meat trade poses to rabies transmission and the ASEAN plus 3 countries' pledge to eliminate rabies by $2020.1-13$.

[3] Albertini AA, Ruigrok RW, Blondel D. 2011. Rabies virus transcription and replication. Adv Virus Res. 79:1-22.

[4] Blancou J. 2008. The control of rabies in Eurasia: overview, history, and background. Dev Biol (Basel). 131:3-15.

[5] Baer GM, editor. 1991. The natural history of rabies. Boca Raton (FL): CRC Press.

[6] Black EM, McElhinney LM, Lowings JP, Smith J, Johnstone P, Heaton PR. 2000. Molecular methods to distinguish between classical rabies and the rabies related European bat lyssa viruses. J Virol Methods. 87:123-131.

[7] Brochier B, Kieny MP, Costy F, Coppens P, Bauduin B, Lecocq JP, Languet B, Chappuis G, Desmetre P, Afiademanyo K, et al. 1991. Large-scale eradication of rabies using recombinant vaccinia rabies vaccine. Nature. 354:520-522.

[8] Banyard AC, Horton DL, Freuling C, Müller T, Fooks AR. 2013. Control and prevention of canine rabies: the need for building laboratory-based surveillance capacity. Antiviral Res. 98(3):357-364.

[9] Banerjee AK. 1987. Transcription and replication of rhabdovirus. Microbiol Rev. 51:66-87.

[10] Bourhy H, Reynes JM, Dunham EJ, Dacheux L, Larrous F, Huong VTQ, Xu G, Yan J, Miranda MEG, Holmes EC. 2008. The origin and phylogeography of dog rabies virus. J Gen Virol. 89:2673-2681.

[11]Cleaveland S, Kaare M, Knobel D, Laurenson MK. 2006. Canine vaccination-providing broader benefits for disease control. Vet Microbiol. 117:43-50.

[12] Consales CA, Bolzan VL. 2007. Rabies review: immunopathology, clinical aspects, and treatment. J Venom Anim Toxins incl Trop Dis. 13(1):5-38.

[13] Chhabra M, Ichhpujani RL. 2003. Animal bites: the current management guidelines. Indian J Pediatr. 70(1): S11-S16.

[14]Dietzschold B, Wunner WH, Wiktor TJ, Lopes AD, Lafon M, Smith CL, Koprowski H. 1983.

www.scirj.org

(C) 2021, Scientific Research Journal

http://dx.doi.org/10.31364/SCIRJ/v9.i02.2021.P0221840

This publication is licensed under Creative Commons Attribution CC BY. 
Characterization of an antigenic determinant of the glycoprotein that correlates with pathogenicity of rabies virus. Proc Natl Acad Sci USA. 80:70-74.

[15] Davis A, Gordy P, Rudd R, Jarvis JA, Bowen RA. 2012. Naturally acquired rabies virus infections in wild-caught bats. Vector-Borne Zoonot Dis. 12(1):55-60.

[16]Dantas-Torres F. 2008. Bats and their role in human rabies epidemiology in the Americas. J Venom Anim Toxins incl Trop Dis. 14(2):193-202.

[17] Dietzschold B, Faber M, Schnell MJ. 2003. New approaches to the prevention and eradication of rabies. Expert Rev Vaccines. 2:399-406.

[18] Francis JR, Nourse C, Vaska VL, Calvert S, Northill JA, McCall B, Mattke AC. 2014. Australian bat lyssavirus in a child: the first reported case. Pediatrics. 133(4): e1063-e1067.

[19] Franka R, Smith TG, Dyer JL, Wu X, Niezgoda M, Rupprecht CE. 2013. Current and future tools for global canine rabies elimination. Antiviral Res. 100(1):220225.

[20] Green SL. 1993. Equine rabies. Vet Clin North Am Equine Pract. 9:337-347.

[21] Hemachudha T, Ugolini G, Wacharapluesadee S, Sungkarat W, Shuangshoti S, Laothamatas J. 2013. Human rabies: neuropathogenesis, diagnosis, and management. Lancet Neurol. 12(5):498-513.

[22] Hanlon C, Childs J. 2013. Epidemiology. In: Jackson A, editor. Rabies scientific basis of the disease and its management. Oxford: Elsevier; p. 61-122.

[23] Haupt W. Rabies - risk of exposure and current trends in prevention of human cases. Vaccine 1999; 17:17421749.

[24] Joseph J, Sangeetha N, Khan AM, Rajoura OP. 2013. Determinants of delay in initiating post-exposure prophylaxis for rabies prevention among animal bite cases: Hospital based study. Vaccine. 32(1):74-77.

[25] Jackson AC. 2000. Rabies in the critical care unit: diagnostic and therapeutic approaches. Can J Neurol Sci. 27:278-282.

[26] Mani RS, Madhusudana SN, Mahadevan A, Reddy V, Belludi AY, Shankar SK. 2014. Utility of real-time Taqman PCR for antemortem and postmortem diagnosis of human rabies. J Med Virol. 86(10):1804-1812.

[27] Noah DL, Drenzek CL, Smith JS, et al. Epidemiology of human rabies in the United States, 1980 to 1996. Ann Intern Med 1998; 128:922-930.

[28] Permpalung N, Wongrakpanich S, Korpaisarn S, Tanratana P, Angsanakul J. 2013. Trend of human rabies prophylaxis in developing countries: Toward optimal rabies immunization. Vaccine. 31(38):40794083.

[29] Pawaiya RVS, Dhama K, Kapoor S, Mahendran M. 2010. Equine rabies. In: Mathew T, editor. Advances in medical and veterinary virology, immunology, and epidemiology - Vol. 7: tropical viral diseases of large domestic animals - Part 1. Philadelphia (PA): Xlibris Corporation Publisher; p. 200-223.
[30] Rupprecht CE, Gibbons RV. 2004. Clinical practice. Prophylaxis against rabies. N Engl J Med. 351(25):2626-2635.

[31] Robardet E, Picard-Meyer E, Andrieu S, Servat A, Cliquet F. 2011. International interlaboratory trials on rabies diagnosis: an overview of results and variation in reference diagnosis techniques (fluorescent antibody test, rabies tissue culture infection test, mouse inoculation test) and molecular biology techniques. J Virol Methods. 177(1):15-25.

[32] Shankar BP. 2009. Advances in diagnosis of rabies. Vet World. 2(2):74-77.

[33] Steele JH, Fernandez PJ. 1991. History of rabies and global aspects. In: Baer GM editor. The Natural History of Rabies. 2nd edn. Boca Raton (FL): CRC Press; p. 126.

[34] Streicker DG, Altizer SM, Velasco-Villa A, Rupprecht CE. 2012. Variable evolutionary routes to host establishment across repeated rabies virus host shifts among bats. Proc Natl Acad Sci. 109(48):19715-19720.

[35] Thanomsridetchai N, Singhto N, Tepsumethanon V, Shuangshoti S, Wacharapluesadee S, Sinchaikul S, Chen ST, Hemachudha T, Thongboonkerd V. 2011. Comprehensive proteome analysis of hippocampus, brainstem, and spinal cord from paralytic and furious dogs naturally infected with rabies. J Proteome Res. 10:4911-4924.

[36] Ugolini G. 1995. Specificity of rabies virus as a transneuronal tracer of motor networks: transfer from hypoglossal motoneurons to connected second order and higher order central nervous system cell groups. J Comp Neurol. 356(3):457-480.

[37] Verma R, Khanna P, Prinja S, Rajput M. 2011. Intradermal administration of rabies vaccines in developing countries: at an affordable cost. Human Vaccine. 7:792794.

[38] Van der Poel WH, Lina PH, Kramps JA. 2006. Public health awareness of emerging zoonotic viruses of bats: a European perspective. Vector Borne Zoonot Dis. 6:315324.

[39] Vos A, Neubert A, Aylan O, Schuster P, Pommerening E, Muller T, Chivatsi DC. 1999. An update on safety studies of SAD B19 rabies virus vaccine in target and non-target species. Epidemiol Infect. 123:165-175.

[40] Weihe E, Bette M, Preuss MA, Faber M, Schafer MK, Rehnelt J, Schnell MJ, Dietzschold B. 2008. Role of virus-induced neuropeptides in the brain in the pathogenesis of rabies. Dev Biol (Basel). 131:73-81.

[41] Wilde H, Hemachudha T, Wacharapluesadee S, Lumlertdacha B, Tepsumethanon V. 2013. Rabies in Asia: the classical zoonosis. In: One health: the humananimal-environment interfaces in emerging infectious diseases. Berlin: Springer; p. 185-203. 